\title{
Operation performance of an A/A/O process coupled with excess sludge ozonation and phosphorus recovery: A pilot-scale study
}

\author{
Zhimin Qiang*, Lu Wang, Huiyu Dong, Jiuhui Qu \\ Key Laboratory of Drinking Water Science and Technology, Research Center for Eco-Environmental Sciences, Chinese Academy of Sciences, 18 Shuang-qing Road, Beijing 100085, China
}

\section{H I G H L I G H T S}

- An A/A/O process coupled with sludge ozonation and $\mathrm{P}$ recovery was developed.

- The sludge solubilization efficiency was $35.5 \%$ at about $100 \mathrm{mg} \mathrm{O}_{3} \mathrm{~g}^{-1}$ MLSS.

- The maximum sludge reduction efficiency reached $85 \%$ in the combined treatment system.

- Ozonated sludge recycle impacted slightly the removal of pollutants (except P).

- The influent P was recovered by $29 \%$ from the supernatant of ozonated sludge.

\section{A R T I C L E I N F O}

\section{Article history:}

Received 15 November 2014

Received in revised form 13 January 2015

Accepted 15 January 2015

Available online 22 January 2015

\section{Keywords:}

Anaerobic/anoxic/oxic process

Sludge ozonation

Phosphorus recovery

Operation performance

Pilot-scale
G R A P H I C A L A B S T R A C T

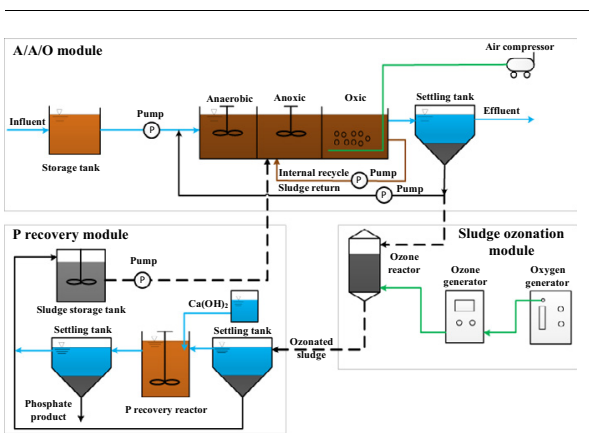

\begin{abstract}
A B S T R A C T
This study investigated the long-term operation performance of an anaerobic/anoxic/oxic $(\mathrm{A} / \mathrm{A} / \mathrm{O})$ process coupled with sludge ozonation and phosphorus $(\mathrm{P})$ recovery at pilot scale with a treatment capacity of $1.0 \mathrm{~m}^{3} \mathrm{~d}^{-1}$. Batch experiments of sludge ozonation showed that the release of organic substances (expressed as chemical oxygen demand (COD)), nitrogen (N), and P from disintegrated microbial cells was enhanced with an increasing ozone dose. The optimal ozone dose was about $100 \mathrm{mg} \mathrm{g}^{-1} \mathrm{MLSS}$ (mixed liquor suspended solids), at which a sludge solubilization efficiency of $35.5 \%$ was achieved. The pilot-scale treatment system was continuously operated for 141 days and a maximum sludge reduction efficiency of $85 \%$ was reached. Ozonated sludge recycle (OSR) affected slightly the COD and $\mathrm{N}$ removal, mixed liquor volatile suspended solids to MLSS ratio, and sludge activity in the bioreactor, and significantly improved the sludge settleability. However, P removal was obviously inhibited because of the reduced discharge of excess sludge. The mass balances of COD and $\mathrm{N}$ indicated that OSR improved both organic mineralization and denitrification. The influent $P$ could be recovered by $29 \%$ from the supernatant of ozonated sludge, thus notably enhancing its removal in the pilot-scale treatment system. This study demonstrates the operational feasibility of the $\mathrm{A} / \mathrm{A} / \mathrm{O}$ process coupled with excess sludge reduction by ozone and P recovery.
\end{abstract}

(C) 2015 Elsevier B.V. All rights reserved.

\footnotetext{
* Corresponding author. Tel.: +86 10 62849632; fax: +86 1062923541.

E-mail address: qiangz@rcees.ac.cn (Z. Qiang).
}

\section{Introduction}

The large amount of excess sludge produced in activated sludge processes has long been a serious problem for wastewater treatment plants (WWTPs) worldwide. In China, the annual production 


\begin{tabular}{|c|c|c|c|}
\hline \multicolumn{4}{|c|}{ Nomenclature } \\
\hline \multirow{2}{*}{\multicolumn{2}{|c|}{ Abbreviations }} & \multirow{4}{*}{$\begin{array}{l}E \\
k\end{array}$} & \multirow{4}{*}{$\begin{array}{l}\text { mass ratio of sludge subjected to ozonation to MLSS in } \\
\text { the bioreactor } \\
\text { MLSS production ratio caused by ozonated sludge re- } \\
\text { cycle }\end{array}$} \\
\hline & & & \\
\hline COD & chemical oxygen demand & & \\
\hline DO & dissolved oxygen & & \\
\hline MLSS & mixed liquor suspended solids & $L_{s}$ & mass ratio of COD removed to MLSS in the bioreactor \\
\hline MLVSS & mixed liquor volatile suspended solids & $M$ & ozone dose ( $\left.\mathrm{mg} \mathrm{g}^{-1} \mathrm{MLSS}\right)$ \\
\hline & nitrogen & $Q$ & flow rate $\left(\mathrm{Ld}^{-1}\right)$ \\
\hline & sludge load & $t$ & time $(\mathrm{d})$ \\
\hline & organic nitrogen & $V$ & volume (L) \\
\hline & ozonated sludge recycle & $X$ & MLSS concentration $\left(\mathrm{g} \mathrm{L}^{-1}\right)$ \\
\hline & phosphorus & $Y_{o b s}$ & 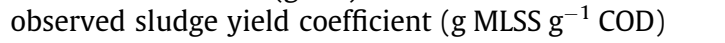 \\
\hline SCOD & soluble chemical oxygen demand & $\eta$ & sludge solubilization efficiency (\%) \\
\hline & sludge retention time & $\sigma$ & sludge reduction efficiency (\%) \\
\hline SVI & sludge volume index & $\sigma_{e}$ & sludge reduction efficiency expected to achieve (\%) \\
\hline TCOD & total chemical oxygen demand & & \\
\hline & total nitrogen & Sub & \\
\hline & total phosphorus & $b r$ & bioreactor \\
\hline & & ef & effluent \\
\hline Symbols & & in & influent \\
\hline & specific decay rate $\left(\mathrm{d}^{-1}\right)$ & or & ozonation reactor \\
\hline C & COD concentration $\left(\mathrm{mg} \mathrm{L}^{-1}\right)$ & os & ozonated sludge \\
\hline & mass ratio of excess sludge to MLSS in the bioreactor & $d$ & daily excess sludge discharge \\
\hline
\end{tabular}

of excess sludge is expected to reach 30 million tons in 2015, given an increasing amount of wastewater to be treated and more stringent standards to be enforced for effluent discharge [1]. The disposal of excess sludge not only increases significantly the total operating cost of WWTPs $[2,3]$, but also poses a great threat to the environment.

Physical, chemical, and biological methods have been developed for sludge reduction based on lysis-cryptic growth, uncoupling metabolism, maintenance metabolism, and predation of microbes [4-6]. Compared with other sludge solubilization techniques such as thermal, ultrasonic and alkaline treatments, ozonation is considered as a promising technology for sludge reduction $[4,7]$. The sludge solubilization efficiency, affected principally by ozone dose and sludge properties, could vary from 20\% to $70 \%$ [6]. Some sludge characteristics (e.g., pH, zeta-potential, and particle size) were altered significantly during ozonation [8-10]. Excess sludge reduction could be achieved within the activated sludge system by combining activated sludge process with sludge ozonation based on lysis-cryptic growth [11-13]. Different combined systems (e.g., anoxic/oxic process coupled with sludge ozonation, sequenced batch reactor coupled with sludge ozonation) have been tested with sludge reduction efficiency of 40-100\% [6]. In our previous work, a conventional activated sludge process coupled with sludge ozonation was operated continuously for 45 days at bench scale without excess sludge discharge at an ozone dose of $100 \mathrm{mg} \mathrm{g}^{-1}$ MLSS (mixed liquor suspended solids) [14]. Moreover, the microbial activity in the bioreactor may be affected by ozonated sludge recycle (OSR) because of the change in the sludge loads $\left(N_{s}\right)$ of the main wastewater quality indicators and the possible inactivation of microbes by ozone. The effluent concentrations of chemical oxygen demand (COD) and total nitrogen (TN) could increase to some extent, whereas that of total phosphorus (TP) could increase significantly, as a result of the reduced discharge of excess sludge [14-16]. In addition, the organic substances released upon sludge solubilization could be used as an internal carbon source for denitrification $[17,18]$, thus reducing wastewater treatment costs.

The large amount of phosphorus $(\mathrm{P})$ rich excess sludge presents a serious challenge to the anaerobic/anoxic/oxic (A/A/O) process, which has been widely employed to reduce nitrogen (N) and P simultaneously in WWTPs. On the one hand, sludge ozonation leads to a reduced discharge of excess sludge. Since $P$ can only be removed through excess sludge discharge in biological treatment processes, it will continuously accumulate in the bioreactor until the treatment process collapses eventually. On the other hand, the gradual depletion of P resources [19] and the undesirable disturbance on aquatic environment (e.g., eutrophication) induced by excessive input of $P$ to water bodies have called for the recovery of $\mathrm{P}$ in WWTPs. Therefore, $\mathrm{P}$ recovery is necessary for the $\mathrm{A} / \mathrm{A} / \mathrm{O}$ process if excess sludge is reduced by ozonation.

In this study, an $\mathrm{A} / \mathrm{A} / \mathrm{O}$ process coupled with sludge ozonation and $P$ recovery was operated to investigate sludge reduction efficiency and wastewater treatment performance. Batch experiments of sludge ozonation were first carried out to determine the optimal ozone dose and the change of sludge characteristics post ozonation. A pilot-scale treatment system was then run for 141 days with different operation phases to examine the sludge reduction efficiency and the fluctuation of effluent quality. With mass balance model calculations, this study demonstrates the feasibility of excess sludge ozonation and $\mathrm{P}$ recovery in the $\mathrm{A} / \mathrm{A} / \mathrm{O}$ process at pilot scale.

\section{Materials and methods}

\subsection{Mass balance model}

An overall mass balance model was developed for a bioreactor coupled with sludge reduction by ozone according to Yasui and Shibata [11] after certain modifications:

$$
\begin{aligned}
V_{b r} \frac{d X_{b r}}{d t}= & Y_{o b s, b r}\left(Q_{i n} C_{i n}-Q_{e f} C_{e f}\right)+k Q_{o r} X_{o r}-Q_{d} X_{d}-Q_{o r} X_{o r} \\
& -b X_{b r} V_{b r}-Q_{e f} X_{e f}
\end{aligned}
$$

Under steady-state conditions, Eq. (2) can be derived (see Text S1 for detailed information):

$Y_{o b s, b r} L_{s}=b+D+\eta E$ 
Hence, the sludge reduction efficiency $(\sigma)$ and the net observed sludge yield coefficient $\left(Y_{o b s, N}\right)$ of the combined treatment process can be calculated as follows:

$\sigma=1-\frac{D_{M}}{D_{0}}=1-\frac{Y_{o b s, b r, M} L_{s, M}-b_{M}-\eta_{M} E_{M}}{Y_{o b s, b r, 0} L_{s, 0}-b_{0}}$

$Y_{o b s, N}=\frac{Y_{o b s, b r, M} L_{s, M}-\eta_{M} E_{M}}{L_{s, M}}$

All the symbols and subscripts in the above equations are defined in the Nomenclature section.

\subsection{Sludge ozonation}

Sludge ozonation was carried out in a cylindrical stainless steel reactor (inner diameter $20 \mathrm{~cm}$, height $120 \mathrm{~cm}$ ) in batch mode to optimize the ozone dose as well as clarify the effects of ozonation on sludge characteristics and the release of COD, N, and P from extracellular polymer degradation and cell lysis. Ozone gas, generated from pure oxygen with an ozone generator (Tonglin, Beijing, China), was bubbled into the sludge through a diffuser disc installed at the reactor bottom. Gaseous ozone concentrations at the inlet (controlled at $45 \mathrm{mg} \mathrm{L}^{-1}$ ) and outlet of the ozonation reactor were both monitored with two ozone meters (Ideal, Zibo, China); the flow rate was set at $1.6 \mathrm{~L} \mathrm{~min}^{-1}$. The exhaust ozone was treated by a catalytic ozone destructor (Jiahuan, Guangzhou, China). Sludge (10 L), with $7.20 \mathrm{~g} \mathrm{~L}^{-1}$ MLSS and $\mathrm{pH} 6.20$, was collected from the settling tank of the $\mathrm{A} / \mathrm{A} / \mathrm{O}$ module and then subjected to ozone treatment in the ozonation reactor (Fig. 1). Sludge solubilization efficiency $(\eta)$ and ozone dose $(M)$ were calculated according to Eqs. (S4) and (S13), respectively. The effect of ozone dose on the release of organic substances from disintegrated microbial cells was examined in terms of the mineralization, solubilization (i.e., liquid-phase), and residual (i.e., solid-phase) ratios of COD (Text S2).

\subsection{Pilot-scale combined treatment system}

The pilot-scale combined treatment system comprised three modules, namely, $\mathrm{A} / \mathrm{A} / \mathrm{O}$, sludge ozonation, and $\mathrm{P}$ recovery
(Fig. 1). The A/A/O module consisted of a bioreactor (anaerobic tank 105.6 L, anoxic tank 105.6 L, and oxic tank $316.8 \mathrm{~L}$ ) and a vertical-flow settling tank ( $50 \mathrm{~L})$. Wastewater temperature was controlled using several thermostats (Jebo, Guangdong, China) installed in the bioreactor and the influent storage tank. The flow rates of the influent, internal recycle, and sludge return were regulated through diaphragm metering pumps (Iwaki, Shanghai, China). The $P$ recovery module consisted of two settling tanks, a $P$ recovery reactor, a $\mathrm{Ca}(\mathrm{OH})_{2}$ tank for $\mathrm{P}$ precipitation, and a sludge storage tank for sludge recycle to the anoxic tank.

Synthetic wastewater containing $328 \mathrm{mg} \mathrm{L}^{-1}$ glucose $\left.\begin{array}{lllll}\left(350 \mathrm{mg} \mathrm{L}^{-1}\right. & \mathrm{COD}\end{array}\right), \quad 134 \mathrm{mg} \mathrm{L}^{-1} \quad \mathrm{NH}_{4} \mathrm{Cl} \quad\left(35 \mathrm{mg} \mathrm{L}^{-1} \quad \mathrm{TN}\right)$ and $13 \mathrm{mg} \mathrm{L}^{-1} \mathrm{KH}_{2} \mathrm{PO}_{4}$ ( $3 \mathrm{mg} \mathrm{L}^{-1} \mathrm{TP}$ ) was prepared with tap water. Trace metals were added as follows: $50 \mu \mathrm{g} \mathrm{L}^{-1} \mathrm{Mo}, \mathrm{Mn}, \mathrm{Zn}, \mathrm{Co}, \mathrm{B}$, $\mathrm{Ni}$ and $\mathrm{Al} ; 30 \mu \mathrm{g} \mathrm{L}^{-1} \mathrm{Cu} ; 20 \mu \mathrm{g} \mathrm{L}^{-1} \mathrm{Mg}$ and $\mathrm{Ca} ; 18 \mu \mathrm{g} \mathrm{L}^{-1} \mathrm{~K}$; and $15 \mu \mathrm{g} \mathrm{L}^{-1} \mathrm{Fe}$. Alkalinity was supplied with $0.15 \mathrm{~g} \mathrm{~L}^{-1} \mathrm{NaHCO}_{3}$, and $\mathrm{pH}$ was controlled at 7.0-7.5. The returned sludge from a municipal wastewater treatment plant (Qinghe, Beijing), with $8603 \mathrm{mg} \mathrm{L}^{-1}$ MLSS, $6185 \mathrm{mg} \mathrm{L}^{-1}$ mixed liquor volatile suspended solids (MLVSS), and pH 6.76, was used as the seeding sludge.

The collected seeding sludge $(70 \mathrm{~L})$ was added to the bioreactor and cultivated with the synthetic wastewater. The pilot-scale combined treatment system was continuously operated for 141 days, which could be divided into five phases. In the startup phase (1$60 \mathrm{~d})$, the sludge return ratio, internal recycle ratio and excess sludge discharge were adjusted to achieve a steady operation status, under which the average MLSS concentration in the bioreactor remained in the range of 3.0-4.0 $\mathrm{g} \mathrm{L}^{-1}$ and the effluent quality conformed to Grade 1-A of the Discharge Standard of Pollutants for Municipal Wastewater Treatment (GB 1898-2002) in China [20]. The $\mathrm{A} / \mathrm{A} / \mathrm{O}$ module was operated under the following conditions: influent flow rate $=1.0 \mathrm{~m}^{3} \mathrm{~d}^{-1}$, hydraulic retention time $=12 \mathrm{~h}$ (anaerobic tank $2.5 \mathrm{~h}$, anoxic tank $2.5 \mathrm{~h}$, and oxic tank $7 \mathrm{~h}$ ), sludge retention time $(S R T)=25 \mathrm{~d}$, sludge return ratio $=33 \%$, internal recycle ratio $=100 \%$. The dissolved oxygen (DO) concentrations in the oxic and anoxic tanks were controlled at about 2.0 and $0.5 \mathrm{mg} \mathrm{L}^{-1}$, respectively. In Phase I (61-95 d), conventional operation strategy was adopted for the A/A/O module (i.e., without sludge ozonation and $\mathrm{P}$ recovery) as experimental control. In Phases II (96-110 d) and III (111-125 d), a certain portion of excess

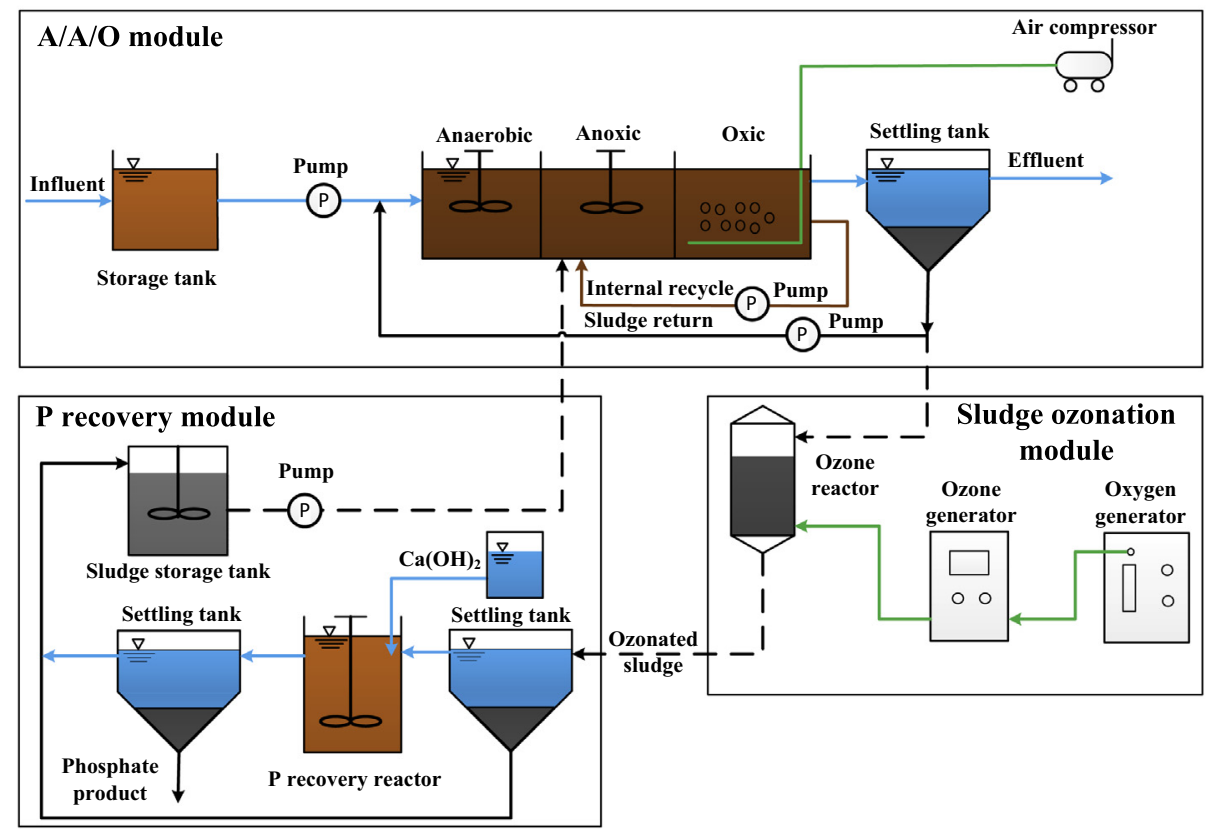

Fig. 1. Schematic diagram of the pilot-scale combined treatment system consisting of three operation modules (A/A/O, sludge ozonation, and P recovery). 
sludge, calculated according to different sludge reduction efficiencies expected to achieve $\left(\sigma_{e}\right)$ (Table S1), was withdrawn from the settling tank, treated in the sludge ozonation module, and then recycled to the bioreactor. The sludge reduction efficiency and treatment performance of the $\mathrm{A} / \mathrm{A} / \mathrm{O}$ module were examined under OSR. In Phase IV (126-141 d), the P recovery module was added after the sludge ozonation module, to precipitate $P$ from the supernatant of ozonated sludge by $\mathrm{Ca}(\mathrm{OH})_{2}$ at a $\mathrm{Ca} / \mathrm{P}$ molar ratio of 10 . After $\mathrm{P}$ recovery, the ozonated sludge was recycled to the bioreactor.

During the entire pilot-scale operation period, the $\mathrm{A} / \mathrm{A} / \mathrm{O}$ module was run continuously, while the sludge ozonation and $\mathrm{P}$ recovery modules were run intermittently each day. The detailed experimental conditions of different operation phases are summarized in Table S1. The excess sludge volumes subjected to ozonation and discharge were calculated according to Eqs. (S11) and (S12) (Text S2), respectively.

\subsection{Analysis}

MLSS, MLVSS, and sludge volume index (SVI) were measured according to the Standard Methods [21]. Supernatant was obtained by filtering the sludge through $0.45 \mu \mathrm{m}$ glass-fiber filters to determine the concentrations of soluble COD (SCOD), TN, ammonia $\left(\mathrm{NH}_{4}^{+}-\mathrm{N}\right)$, nitrite $\left(\mathrm{NO}_{2}^{-}-\mathrm{N}\right)$, nitrate $\left(\mathrm{NO}_{3}^{-}-\mathrm{N}\right), \mathrm{TP}$, and phosphate $\left(\mathrm{PO}_{4}^{3-}-\mathrm{P}\right)$. Hach methods were used to determine the concentrations of COD (method 8000), TN (methods 10,071 and 10,072), $\mathrm{NH}_{4}^{+} \mathrm{N}$ (methods 10,023 and 10,031), $\mathrm{NO}_{2}^{-}-\mathrm{N}$ (method 10,019), $\mathrm{NO}_{3}^{-}-\mathrm{N}$ (methods 10,020 and TNT 836), TP (methods 10,127 and 8190 ), and $\mathrm{PO}_{4}^{3-}-\mathrm{P}$ (method 8000 ) with a DR2800 UV-Vis spectrophotometer and a DRB200 digestion device (Hach, Shanghai, China). The wastewater temperature and DO concentration were monitored online with a mercurial thermometer and a portable DO meter (WTW, Munich, Germany), respectively. All the analyses were performed in duplicate.

\section{Results and discussion}

\subsection{Excess sludge ozonation}

The change of sludge solubilization efficiency $(\eta)$ and the release of COD, N and P as a function of ozone dose are shown in Fig. 2. The results indicate that the $\eta$ increased quickly to $35.5 \%$ as the ozone dose increased to $101 \mathrm{mg} \mathrm{g}^{-1}$ MLSS; afterwards, a slow increase was observed as the ozone dose further increased to $207 \mathrm{mg} \mathrm{g}^{-1}$ MLSS (Fig. 2a), which was attributed to the enhanced competition of soluble components for ozone against particulate matter [22] and the inhibition on indirect oxidations by radical scavengers (e.g., lactic acid) released from disintegrated microbial cells [8]. The optimal ozone dose was about $100 \mathrm{mg} \mathrm{g}^{-1}$ MLSS, as a tradeoff between $\eta$ and treatment cost.

Fig. 2b shows that in the ozone dose range of $0-101 \mathrm{mg} \mathrm{g}^{-1}-$ MLSS, the total COD (TCOD) concentration remained almost constant, with a slight increase in the COD mineralization ratio from $0 \%$ to $1.2 \%$; however, the SCOD concentration increased remarkably from 34 to $2650 \mathrm{mg} \mathrm{L}^{-1}$, in correspondence to a rapid increase in the COD solubilization ratio from $0.4 \%$ to $29.1 \%$. When the ozone dose was further increased to $207 \mathrm{mg} \mathrm{g}^{-1}$ MLSS, the COD mineralization ratio increased relatively fast to $7.2 \%$, whereas the COD solubilization ratio increased relatively slowly to $32.4 \%$. The results indicate that below $101 \mathrm{mg} \mathrm{O}_{3} \mathrm{~g}^{-1}$ MLSS, ozone was mainly consumed for sludge solubilization; while above this value, ozone was mainly consumed for sludge mineralization. The residual sludge became more refractory to oxidation as ozone dose increased; meanwhile, the organic substances released into the

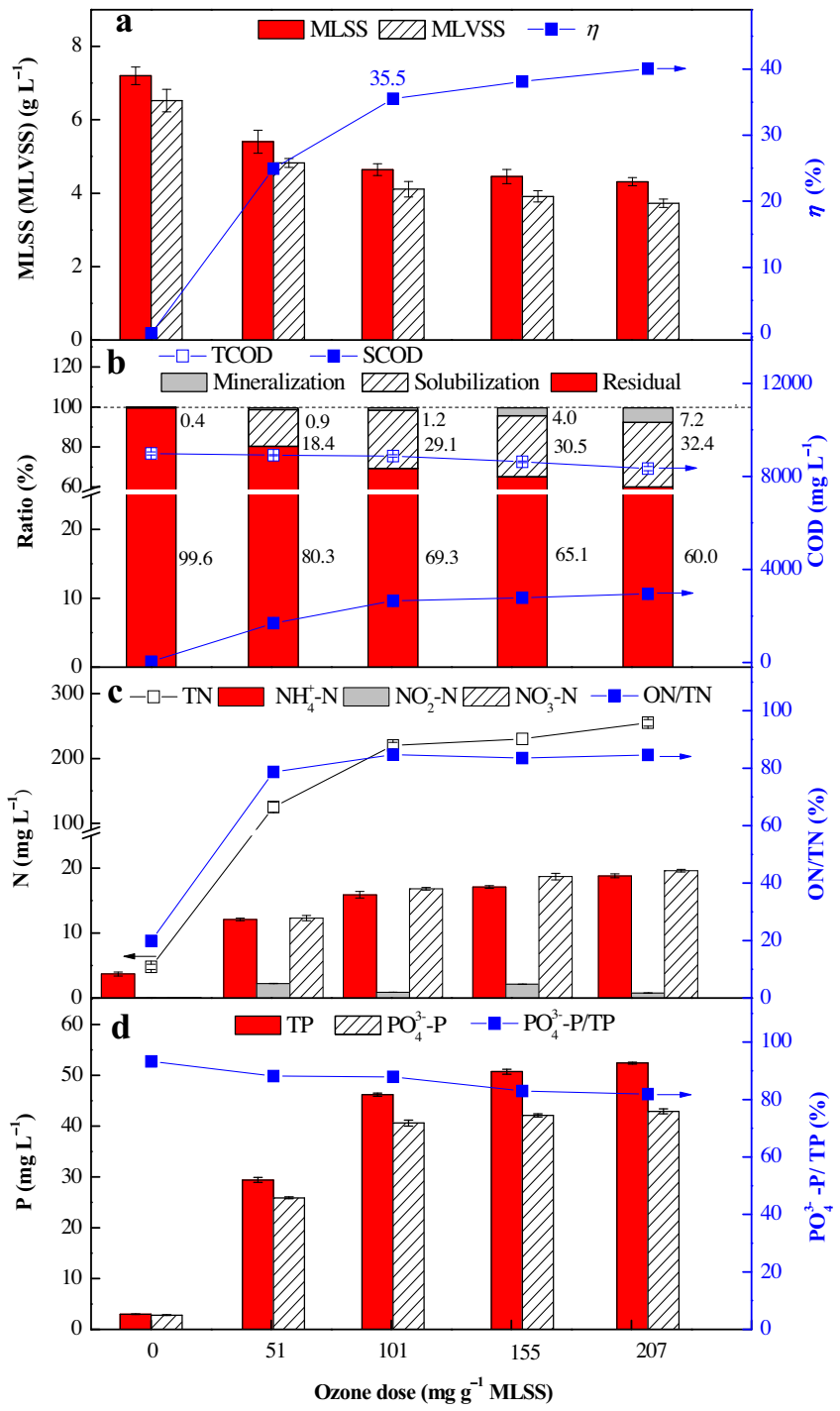

Fig. 2. Changes of sludge solubilization efficiency (a), COD (b), N (c), and P (d) with ozone dose during sludge ozonation. Error bars represent the standard deviation of triplicate experiments.

supernatant were partially mineralized by ozone. However, there is no need to mineralize the soluble organic substances because they can provide additional carbon source to promote denitrification in the $\mathrm{A} / \mathrm{A} / \mathrm{O}$ process [23].

The concentrations of $\mathrm{TN}, \mathrm{NH}_{4}^{+}-\mathrm{N}$ and $\mathrm{NO}_{3}^{-}-\mathrm{N}$ increased rapidly from $4.8,3.7$ and $0.1 \mathrm{mg} \mathrm{L}^{-1}$ to $220,15.9$ and $16.8 \mathrm{mg} \mathrm{L}^{-1}$ in the ozone dose range of $0-101 \mathrm{mg} \mathrm{g}^{-1}$ MLSS, respectively, and then increased slowly to $255,18.8$ and $19.6 \mathrm{mg} \mathrm{L}^{-1}$ at $207 \mathrm{mg} \mathrm{O}_{3} \mathrm{~g}^{-1}$ MLSS; while the $\mathrm{NO}_{2}^{-}-\mathrm{N}$ concentration always maintained at a low level ( $<2.3 \mathrm{mg} \mathrm{L}^{-1}$ ) (Fig. 2c). The main $\mathrm{N}$ species released into the supernatant was organic nitrogen $(\mathrm{ON})$, whose proportion reached $85 \%$ of $\mathrm{TN}$ at $101 \mathrm{mg} \mathrm{O}_{3} \mathrm{~g}^{-1}$ MLSS and then remained almost constant. In addition, the concentrations of $\mathrm{TP}$ and $\mathrm{PO}_{4}^{3-}-\mathrm{P}$ increased remarkably from 3.0 and $2.8 \mathrm{mg} \mathrm{L}^{-1}$ to 46.2 and $40.6 \mathrm{mg} \mathrm{L}^{-1}$ in the ozone dose range of $0-101 \mathrm{mg} \mathrm{g}^{-1}$ MLSS, respectively, and then increased slowly with an increasing ozone dose (Fig. 2d). The main $\mathrm{P}$ species released into the supernatant was $\mathrm{PO}_{4}^{3-}$-P (e.g., $88 \%$ of TP at $101 \mathrm{mg} \mathrm{O}_{3} \mathrm{~g}^{-1} \mathrm{MLSS}$ ), which could facilitate $\mathrm{P}$ recovery.

The effect of ozone dose on sludge characteristics is manifested in Table S2. The sludge pH dropped obviously from 6.2 to 4.2 as the 
ozone dose increased from 0 to $207 \mathrm{mg} \mathrm{g}^{-1}$ MLSS, because ozonation of organic substances could produce various organic acids [24]. The MLVSS/MLSS ratio decreased from $90.6 \%$ to $86.4 \%$, implying that a certain portion of the organic content of sludge was mineralized by ozone. The SVI gradually decreased from 77.8 to $62.6 \mathrm{~mL} \mathrm{~g}^{-1}$ with an increasing ozone dose, indicating an improved settleability of the ozonated sludge.

\subsection{Effluent quality of the pilot-scale treatment system}

Fig. 3 shows the effluent quality and the removal efficiencies of COD, TN, $\mathrm{NH}_{4}^{+}-\mathrm{N}$, and TP in the pilot-scale treatment system over the entire operation period. In Phase I, the mean effluent concentrations of COD, TN and TP were measured to be 17, 10.9, and $0.33 \mathrm{mg} \mathrm{L}^{-1}$, respectively; while the effluent concentration of $\mathrm{NH}_{4}^{+}-\mathrm{N}$ decreased gradually and reached stable at $0.4 \mathrm{mg} \mathrm{L}^{-1}$ in the last six days. In Phases II and III, different proportions of excess sludge (i.e., $\sigma_{e}=50 \%$ and $70 \%$, respectively) were withdrawn from the settling tank, ozonated, and then recycled to the bioreactor. The effluent concentrations of $\mathrm{COD}, \mathrm{TN}$, and $\mathrm{NH}_{4}^{+}-\mathrm{N}$ remained stable with mean concentrations of $18,11.3$, and $0.3 \mathrm{mg} \mathrm{L}^{-1}$, respectively. However, the effluent concentration of TP kept increasing

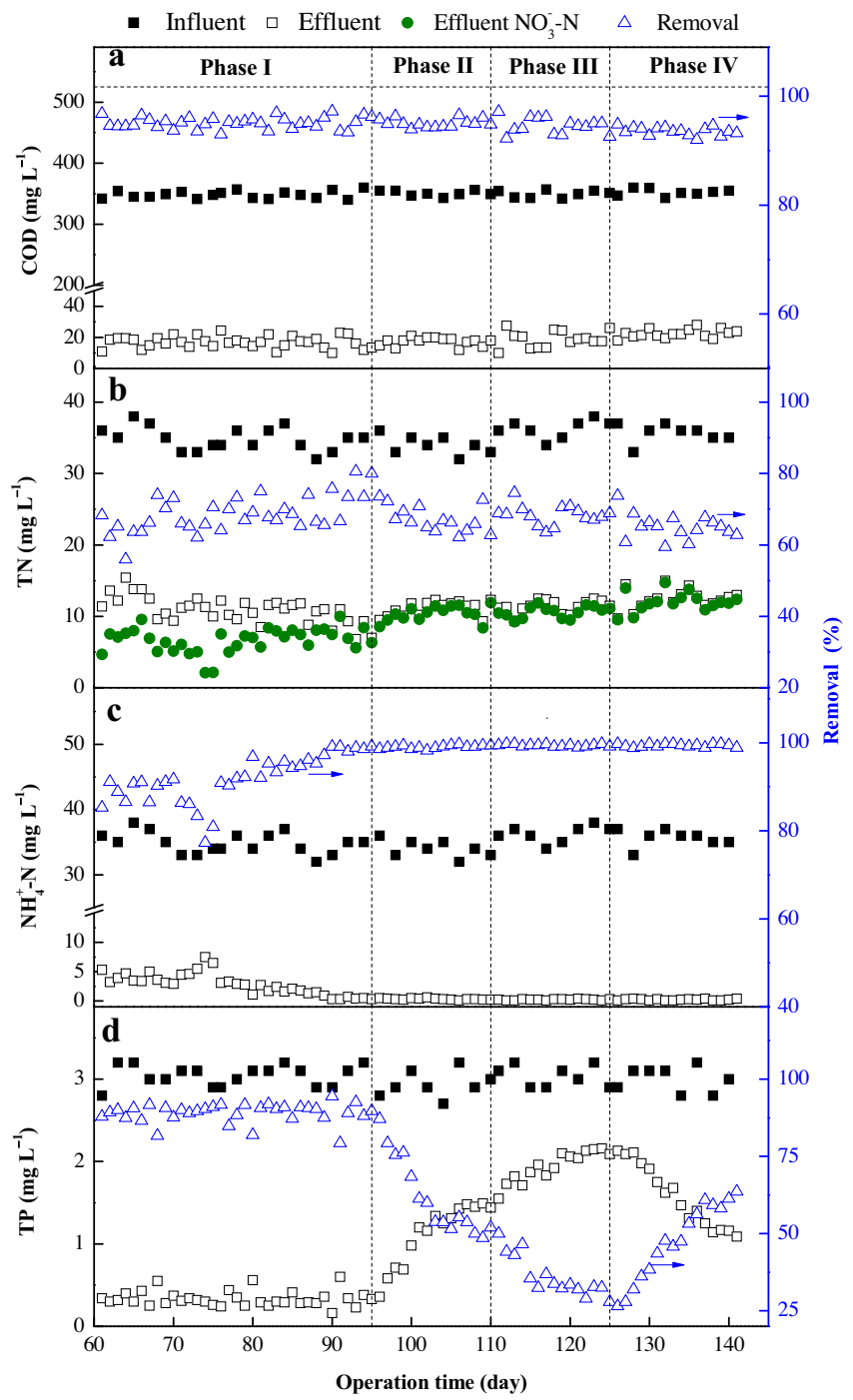

Fig. 3. Continuous operation performance of the pilot-scale treatment system in terms of $\operatorname{COD}(\mathrm{a}), \mathrm{TN}(\mathrm{b}), \mathrm{NH}_{4}^{+}-\mathrm{N}(\mathrm{c})$, and TP (d). Phase I: A/A/O; Phase II-III: A/A/ $\mathrm{O}+$ sludge ozonation; Phase IV: A/A/O + sludge ozonation + $\mathrm{P}$ recovery. until it became quite stable in the last few days of Phases II (1.46 $\left.\mathrm{mg} \mathrm{L}^{-1}\right)$ and III $\left(2.10 \mathrm{mg} \mathrm{L}^{-1}\right)$. It is seen that $\mathrm{P}$ accumulated in the bioreactor because of the OSR and the reduced discharge of excess sludge. In Phase IV, a $\mathrm{P}$ recovery module was added between the $\mathrm{A} / \mathrm{A} / \mathrm{O}$ and the sludge ozonation modules, which could remove most of the supernatant $\mathrm{P}(>85 \%)$ in the ozonated sludge. $\mathrm{P}$ recovery had an insignificant influence on the effluent concentrations of $\mathrm{COD}, \mathrm{TN}$, and $\mathrm{NH}_{4}^{+}-\mathrm{N}$; while the effluent concentration of TP decreased gradually until a new stable level was reached in the last four days (i.e., $1.14 \mathrm{mg} \mathrm{L}^{-1}$ ).

The removal efficiencies of $\mathrm{COD}, \mathrm{TN}$, and $\mathrm{NH}_{4}^{+}-\mathrm{N}$ showed small fluctuations during the entire operation period, probably because of the relatively constant sludge loads $\left(N_{s}\right)$ of these wastewater quality indicators (Table S3). This result coincides with those reported by other researchers, who found no or only a slight change in the effluent COD and TN concentrations after OSR [2527]. The OSR did not inhibit the nitrification and denitrification in the bioreactor, as supported by the facts that the effluent concentration of TN maintained nearly constant and $\mathrm{NO}_{3}^{-}-\mathrm{N}$ was always its predominant species in Phases II-IV (87-98\%). However, although the $N_{s}$ of TP remained quite stable during the entire operation period (1.5-1.9 $\mathrm{g} \mathrm{kg}^{-1} \mathrm{~d}^{-1}$ ), (Table S3), a significant decline in $P$ removal was observed in Phases II and III because P can only be removed through excess sludge discharge in biological processes. Hence, the $P$ recovery module is necessary for sustainable and long-term operation of the $\mathrm{A} / \mathrm{A} / \mathrm{O}$ process coupled with excess sludge reduction by ozone.

\subsection{Sludge reduction efficiency and sludge characteristics of the pilot- scale treatment system}

Table 1 shows the calculated values of the sludge reduction efficiency $(\sigma)$ and the observed sludge yield coefficient $\left(Y_{o b s}\right)$ in different operation phases according to the mass balance model (Text S1). The calculated sludge reduction efficiencies $\left(\sigma_{1}\right)$, if the variation of MLSS in the bioreactor was considered, were $59 \%, 72 \%$, and $85 \%$ from Phase II to IV, respectively. These values were higher than those expected $\left(\sigma_{e}\right.$, Table S1). If the variation of MLSS was ignored, the sludge reduction efficiencies ( $\sigma_{2}$; specifically, $48 \%$, $66 \%$ and $72 \%$ ) approached the $\sigma_{e}$ values more closely in Phases II-IV (Table 1).

The observed sludge yield coefficients of the pilot-scale treatment system $\left(Y_{o b s, C}\right)$ in different operation phases could be obtained through linear fitting of the accumulated sludge production vs. the accumulated COD removal (Fig. 4). The results indicate that the $Y_{o b s, C}$ decreased stepwise from Phase I to IV (i.e., 0.24, 0.11, 0.08 , and $0.04 \mathrm{~g} \mathrm{MLSS}^{-1} \mathrm{COD}$ ), which was approximately equal to the net observed sludge yield coefficient $\left(Y_{o b s, N}\right.$, Table 1$)$ theoretically calculated according to Eq. (4). If Phase I was taken as a reference, the reduction percentages of $Y_{o b s, C}$ from Phase II to IV were calculated as $54 \%, 67 \%$, and $83 \%$, respectively, which were quite close to the corresponding $\sigma_{1}$ values (Table 1 ). These results

Table 1

The calculated values of $Y_{o b s}$ and $\sigma$ in different operation phases.

\begin{tabular}{lllll}
\hline Parameters & Phase I & Phase II & Phase III & Phase IV \\
\hline$\sigma_{1}(\%)^{\mathrm{a}}$ & 0 & 59 & 72 & 85 \\
$\sigma_{2}(\%)^{\mathrm{a}}$ & 0 & 48 & 66 & 72 \\
$Y_{o b s, b r}\left(\mathrm{~g} \mathrm{MLSS} \mathrm{g}^{-1} \mathrm{COD}\right)^{\mathrm{b}}$ & 0.24 & 0.21 & 0.22 & 0.19 \\
$Y_{o b s, N}\left(\mathrm{~g} \mathrm{MLSS} \mathrm{g}^{-1} \mathrm{COD}\right)^{\mathrm{b}}$ & 0.24 & 0.10 & 0.07 & 0.04 \\
\hline
\end{tabular}

${ }^{\mathrm{a}} \sigma_{1}$ and $\sigma_{2}$ represent the calculated sludge reduction efficiencies according to the mass balance model with and without the consideration of MLSS variation, respectively.

b $Y_{o b s, b r}$ and $Y_{o b s, N}$ represent the theoretically calculated observed sludge yield coefficients for the bioreactor and the combined process according to the mass balance model, respectively. 


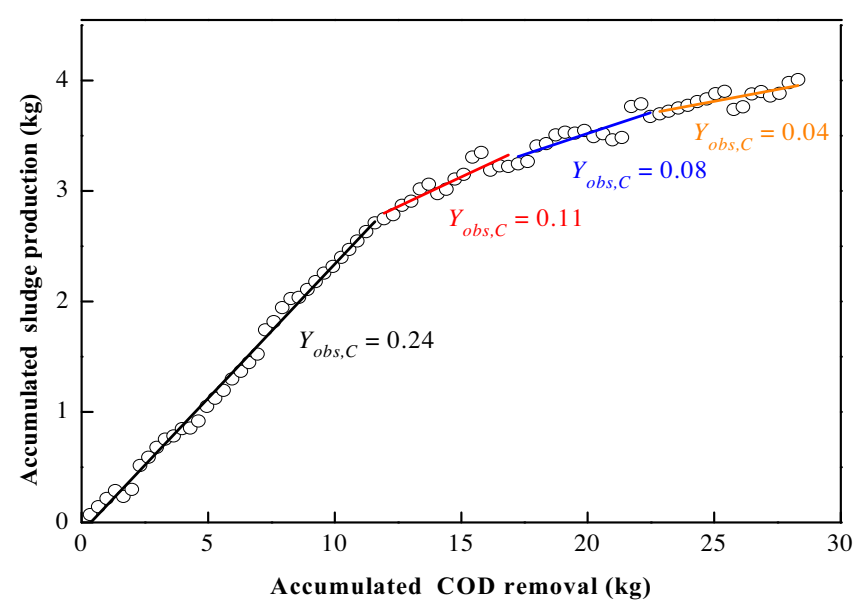

Fig. 4. Observed sludge yield coefficients in different operation phases of the pilotscale treatment system.

confirm that the developed mass balance model was well applicable to evaluate the sludge reduction efficiencies during different operation phases of the pilot-scale treatment system.

The effect of OSR on sludge characteristics in the bioreactor was also examined. The MLSS and MLVSS concentrations in the bioreactor kept increasing from the startup to Phase III and then decreased slightly in Phase IV after the $\mathrm{P}$ recovery module was added (Table S1). However, the ratio of MLVSS/MLSS remained nearly constant in all the three chambers (i.e., anaerobic, aerobic, and oxic) of the bioreactor throughout the entire operation period; meanwhile, a notable decrease in SVI was observed in each chamber, indicating an improved sludge settleability through OSR (Fig. S1). In addition, the similar observed sludge yield coefficients in the bioreactor $\left(Y_{o b s, b r}\right)$ among different operation phases reveal that the sludge activity was well maintained (Table 1), which explains the stable COD removal throughout the entire operation period as aforementioned.

\subsection{Mass balance of the pilot-scale treatment system}

Fig. 5 illustrates the overall mass balances of COD and $\mathrm{N}$ in different operation phases of the pilot-scale treatment system. The outputs of COD and $\mathrm{N}$ comprised three pathways: gas emission $\left(\mathrm{CO}_{2}\right.$ and $\left.\mathrm{N}_{2}\right)$, effluent discharge, and excess sludge discharge. The ratios of $0.8 \mathrm{~g} \mathrm{MLSS}^{-1}$ TCOD (determined in this study) and $0.07 \mathrm{~g} \mathrm{~N} \mathrm{~g}^{-1}$ TCOD [28] were adopted to evaluate the amounts of COD and $\mathrm{N}$ discharged with excess sludge, respectively. From Phase I to II, the emitted proportions of COD and N increased notably by $16 \%$ and $9 \%$, respectively, indicating that OSR could improve both organic mineralization and denitrification. The proportions of COD and $\mathrm{N}$ discharged with excess sludge decreased accordingly because the excess sludge was partially reduced by ozonation. The effluent proportions of COD and $\mathrm{N}$ had little change if the influent quality fluctuation was considered, indicating that OSR had an insignificant influence on the removal of COD and N. From Phase II to IV, the three proportions of COD and $\mathrm{N}$ only exhibited small variations. The ozonated sludge was recycled to the anoxic tank which had an insufficient carbon source $(\mathrm{COD} / \mathrm{TN}<5)$. The improved denitrification demonstrated that the organic substances released upon sludge ozonation could be used as an additional carbon source by denitrifying bacteria, as also reported in previous studies $[29,30]$.

The daily mass balance of $P$ in different operation phases is shown in Fig. 6. The output of $\mathrm{P}$ consisted of two pathways (i.e., effluent discharge and excess sludge discharge) from Phase I to III, and three pathways (i.e., effluent discharge, excess sludge discharge, and $\mathrm{P}$ recovery) in Phase IV. The P/MLSS mass ratio of $3.7 \%$ (determined in this study) was used to calculate the amount of $P$ discharged with excess sludge. In Phase I, the input and output of P were roughly balanced. However, from Phase II to IV, the balance was disturbed by excess sludge reduction and $\mathrm{P}$ recovery. The effluent P increased obviously in Phases II and III, and then decreased gradually in Phase IV until it reached a fairly stable level in the last few days. This balance disturbance arose from the accumulation and release of $\mathrm{P}$ in the bioreactor. According to our measurement data, about $29 \%$ of the influent $\mathrm{P}$ was removed in the $P$ recovery module. If $100 \%$ of excess sludge reduction was achieved at an ozone dose of about $100 \mathrm{mg} \mathrm{g}^{-1}$ MLSS, the $P$ recovery module could remove $41 \%$ of the influent $P$. Note that $P$ recovery from the supernatant of ozonated sludge was controlled by the ozone dose applied and the amount of excess sludge treated, which reached maximum when a complete sludge reduction was achieved. To further enhance its removal in the combined treatment system, P may also be recovered from
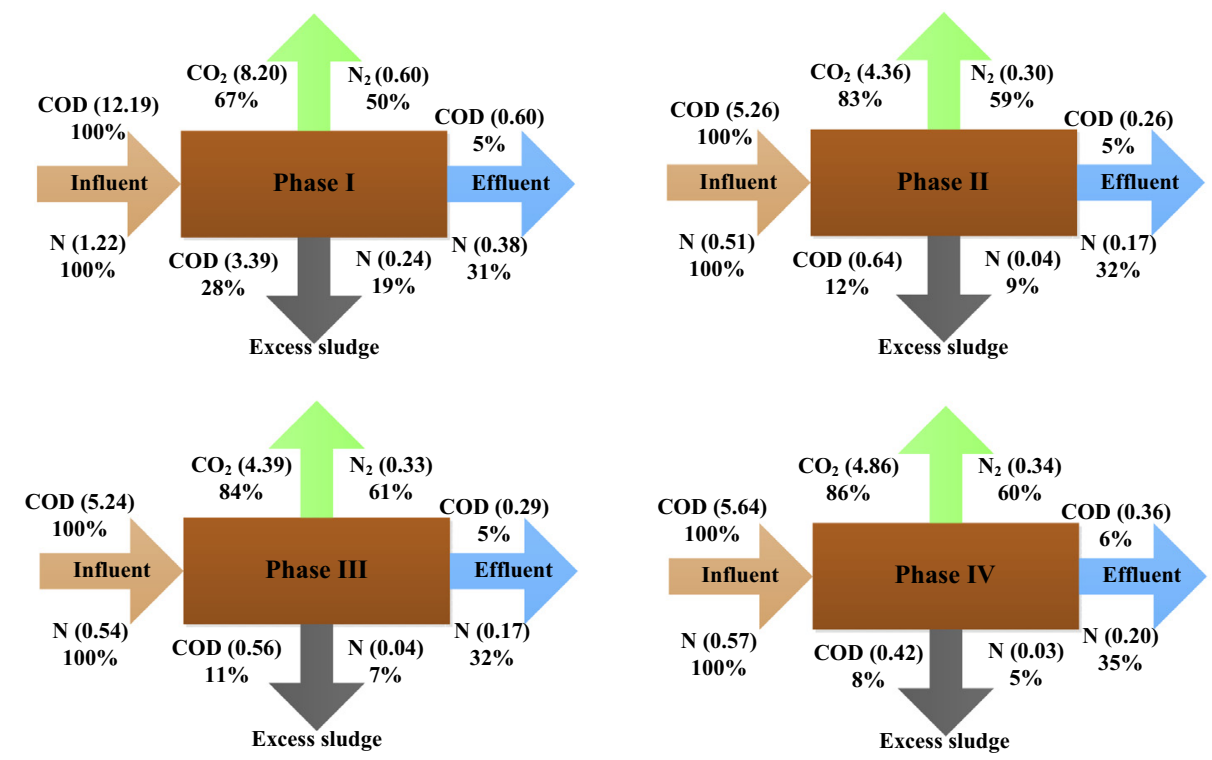

Fig. 5. Overall mass balances of COD and $\mathrm{N}$ in different operation phases of the pilot-scale treatment system (unit of the parenthesized numbers: kg). 


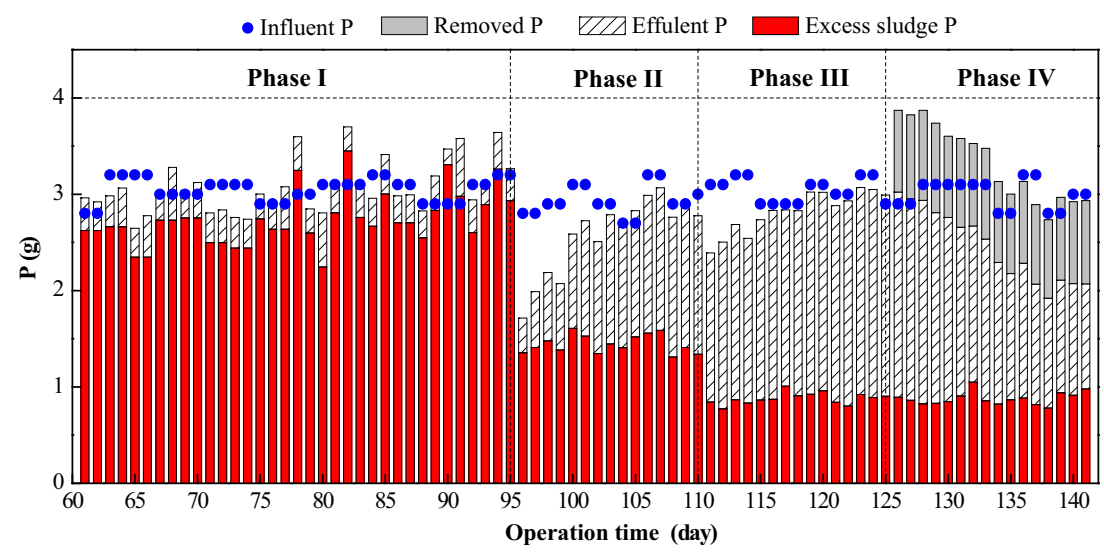

Fig. 6. Daily mass balance of $P$ in different operation phases of the pilot-scale treatment system.

the supernatant of anaerobic tank [31], in addition to the supernatant of ozonated sludge.

\section{Conclusions}

This study investigated the long-term operation performance of an $\mathrm{A} / \mathrm{A} / \mathrm{O}$ process coupled with excess sludge ozonation and $\mathrm{P}$ recovery at pilot scale. Based on the experimental results obtained, the following conclusions can be drawn:

- The release of COD, $\mathrm{N}$ and $\mathrm{P}$ from cell lysis during sludge ozonation was enhanced as ozone dose increased. The optimal ozone dose was about $100 \mathrm{mg} \mathrm{g}^{-1}$ MLSS, at which a sludge solubilization efficiency of $35.5 \%$ was achieved.

- The pilot-scale combined treatment system achieved a maximum sludge reduction efficiency of $85 \%$. OSR had little effect on COD and $\mathrm{N}$ removal, MLVSS/MLSS ratio, and sludge activity in the bioreactor, and significantly improved the sludge settleability. However, it obviously increased the effluent TP concentration.

- The mass balances of COD, N, and P showed that OSR could improve both organic mineralization and denitrification in the bioreactor, and the $\mathrm{P}$ recovery module could recover $29 \%$ of the input $P$.

- Future studies will focus on P recovery from the supernatants of both anaerobic tank and ozonated sludge, so as to further enhance its removal in the pilot-scale combined treatment system.

\section{Acknowledgements}

This study was financially supported by the National Natural Science Foundation of China $(51221892,21277160)$ and Siemens Ltd., China (Technical study on sludge source reduction).

\section{Appendix A. Supplementary data}

Supplementary data associated with this article can be found, in the online version, at http://dx.doi.org/10.1016/j.cej.2015.01.054.

\section{References}

[1] L. Wang, Z.M. Qiang, H.Y. Dong, Y.F. Lu, Y.F. Nie, Sludge reduction by ozone in municipal wastewater treatment plants, Acta Sci. Circumst. 34 (2014) 363-369 (in Chinese).
[2] P. Liang, X. Huang, Y. Qian, Y.S. Wei, G.J. Ding, Determination and comparison of sludge reduction rates caused by microfaunas' predation, Bioresour. Technol. 97 (2006) 854-861.

[3] J.L. Campos, L. Otero, A. Franco, A. Mosquera-Corral, E. Roca, Ozonation strategies to reduce sludge production of a seafood industry WWTP, Bioresour. Technol. 100 (2009) 1069-1073.

[4] Y.S. Wei, R.T. Van Houten, A.R. Borger, D.H. Eikelboom, Y.B. Fan, Minimization of excess sludge production for biological wastewater treatment, Water Res. 37 (2003) 4453-4467.

[5] X. Huang, P. Liang, Y. Qian, Excess sludge reduction induced by Tubifex tubifex in a recycled sludge reactor, J. Biotechnol. 127 (2007) 443-451.

[6] L.B. Chu, S.T. Yan, X.H. Xing, X.L. Sun, B. Jurcik, Progress and perspectives of sludge ozonation as a powerful pretreatment method for minimization of excess sludge production, Water Res. 43 (2009) 1811-1822.

[7] K.Y. Park, K.H. Ahn, S.K. Maeng, J.H. Hwang, J.H. Kwon, Feasibility of sludge ozonation for stabilization and conditioning, Ozone Sci. Eng. 25 (2003) 73-80.

[8] S.T. Yan, L.B. Chu, X.H. Xing, A.F. Yu, X.L. Sun, B. Jurcik, Analysis of the mechanism of sludge ozonation by a combination of biological and chemical approaches, Water Res. 43 (2009) 195-203.

[9] G.M. Zhang, J. Yang, H.Z. Liu, J. Zhang, Sludge ozonation: disintegration, supernatant changes and mechanisms, Bioresour. Technol. 100 (2009) 15051509.

[10] P.Z. Sui, F. Nishimura, H. Nagare, T. Hidaka, Y. Nakagawa, H. Tsuno, Behavior of inorganic elements during sludge ozonation and their effects on sludge solubilization, Water Res. 45 (2011) 2029-2037.

[11] H. Yasui, M. Shibata, An innovative approach to reduce excess sludge production in the activated sludge process, Water Sci. Technol. 30 (1994) $11-20$.

[12] H. Yasui, K. Nakamura, S. Sakuma, M. Iwasaki, Y. Sakai, A full-scale operation of a novel activated sludge process without excess sludge production, Water Sci. Technol. 34 (1996) 395-404.

[13] E. Egemen, J. Corpening, J. Padilla, R. Brennan, N. Nirmalakhandan, Evaluation of ozonation and cryptic growth for biosolids management in wastewater treatment, Water Sci. Technol. 39 (1999) 155-158.

[14] Y.F. Nie, Z.M. Qiang, W.W. Ben, J.X. Liu, Removal of endocrine-disrupting chemicals and conventional pollutants in a continuous-operating activated sludge process integrated with ozonation for excess sludge reduction, Chemosphere 105 (2014) 133-138.

[15] A. Huysmans, M. Weemaes, P.A. Fonseca, W. Verstraete, Ozonation of activated sludge in the recycle stream, J. Chem. Technol. Biotechnol. 76 (2001) 321-324.

[16] J.W. Lee, H.Y. Cha, K.Y. Park, K.G. Song, K.H. Ahn, Operational strategies for an activated sludge process in conjunction with ozone oxidation for zero excess sludge production during winter season, Water Res. 39 (2005) 1199-1204.

[17] J. Tong, Y.G. Chen, Recovery of nitrogen and phosphorus from alkaline fermentation liquid of waste activated sludge and application of the fermentation liquid to promote biological municipal wastewater treatment, Water Res. 43 (2009) 2969-2976.

[18] S. Yang, Q.H. Wang, T. Zhang, P. Li, C.F. Wu, Biological nitrogen removal using the supernatant of ozonized sludge as extra carbon source, Ozone Sci. Eng. 33 (2011) 410-416.

[19] I. Steen, Phosphorus availability in the 21st century: management of a nonrenewable resource, Phosphorus Potassium 217 (1998) 25-31.

[20] MEP, AOSIQ Discharged Standard of Pollutants for Municipal Wastewater Treatment Plant, Chinese Environment Press, Beijing, 2002.

[21] APHA, AWWA, WEF, Standard Methods for the Examination of Water and Wastewater, 22nd ed., American Public Health Association, Washington D.C. USA, 2012.

[22] D. Cesbron, S. Deleris, H. Debellefontaine, M. Roustan, E. Paul, Study of competition for ozone between soluble and particulate matter during activated sludge ozonation, Chem. Eng. Res. Des. 81 (2003) 1165-1170.

[23] R. Cui, D. Jahng, Nitrogen control in AO process with recirculation of solubilized excess sludge, Water Res. 38 (2004) 1159-1172. 
[24] M. Weemaes, H. Grootaerd, F. Simoens, W. Verstraete, Anaerobic digestion of ozonized biosolids, Water Res. 34 (2000) 2330-2336.

[25] T. Kamiya, J. Hirotsuji, New combined system of biological process and intermittent ozonation for advanced wastewater treatment, Water Sci. Technol. 38 (1998) 145-153.

[26] S. Deleris, V. Geauge, P. Camacho, H. Debelletontaine, E. Paul, Minimization of sludge production in biological processes processes an alternative solution for the problem of sludge disposal, Water Sci. Technol. 46 (2002) 63-70.

[27] A. Chiavola, M. Naso, E. Rolle, D. Trombetta, Effect of ozonation on sludge reduction in a SBR plant, Water Sci. Technol. 56 (2007) 157-165.

[28] M. Henze, W. Gujer, T. Mino, T. Matsuo, M.C. Wentzel, G.V.R. Marais, M.C.M. Van Loosdrecht, Activated sludge model NO. 2D, ASM2D, Water Sci. Technol. 39 (1999) 165-182.
[29] M. Bohler, H. Siegrist, Partial ozonation of activated sludge to reduce excess sludge, improve denitrification and control scumming and bulking, Water Sci. Technol. 49 (2004) 41-49.

[30] M.A. Dytczak, K.L. Londry, H. Siegrist, J.A. Oleszkiewicz, Ozonation reduces sludge production and improves denitrification, Water Res. 41 (2007) 543550.

[31] W. Saktaywin, H. Tsuno, H. Nagare, T. Soyama, Operation of a new sewage treatment process with technologies of excess sludge reduction and phosphorus recovery, Water Sci. Technol. 53 (2006) 217-227. 